\title{
Access to foods using Grand Rapids, Michigan, as a case study: Objective versus subjective issues
}

\author{
Zeenat Kotval-K, ${ }^{a} *$ Shruti Khandelwal, ${ }^{\mathrm{b}}$ and Kendra Wills ${ }^{\mathrm{c}}$ \\ Michigan State University
}

\begin{abstract}
Submitted June 29, 2020 / Revised October 26, November 13, December 8, 2020, and January 6, 2021 /
Accepted January 7, 2021 / Published online May 19, 2021

Citation: Kotval-K, Z., Khandelwal, S., \& Wills, K. (2021). Access to foods using Grand Rapids, Michigan, as a case study: Objective versus subjective issues. Journal of Agriculture, Food Systems, and Community

Development, 10(3), 145-159. https://doi.org/10.5304/jafscd.2021.103.008
\end{abstract}

Copyright (C) 2021 by the Authors. Published by the Lyson Center for Civic Agriculture and Food Systems. Open access under CC-BY license.

\begin{abstract}
Low access and low income are two of the primary factors used in determining the food desert designation by the U.S. Department of Agriculture. Low access is defined as a geographical area where 33\% or more people are living beyond one mile from a supermarket in an urban region, and a low-income area is defined as one with a poverty rate of either $20 \%$ or more, or median family income falling below $80 \%$ of statewide or metropolitan area family income. These criteria have been in place for several years now. This study aims to assess the adequacy of these criteria for food desert designation and further investigate perceptions of barriers to fresh and healthy foods and measure physical 'access' for those reliant on the public transporta-

a * Corresponding author: Zeenat Kotval-K, Ph.D., AICP, Assistant Professor of Urban \& Regional Planning, School of Planning, Design \& Construction, Michigan State University; 552 West Circle Drive, Room 404; East Lansing, MI 48824 USA; +1-517-353-5460; kotvalze@msu.edu

b Shruti Khandelwal, Doctoral Student in Planning, Design \& Construction, School of Planning, Design \& Construction, Michigan State University; 552 West Circle Drive, Room 404; East Lansing, MI 48824 USA; khandel8@msu.edu
\end{abstract}

tion in the city of Grand Rapids, Michigan. The study includes a preliminary price comparative analysis of selected fresh foods in local grocery stores, spatial mapping using GIS to measure accessibility, and interviews with families at three schools located in food desert census tracts.

Results of this study indicate that, first, there are other factors to consider when designating areas as food deserts such as public transit availability and inclusion of alternate food retail stores where fresh and healthy foods may be purchased, and secondly, perceptions of barriers to access fresh and healthy foods for families depend on mobility and cost preferences. Implications include a greater awareness of transit availability, alternate venues, acceptance of federal benefits such as SNAP-EBT, and incentivizing existing stores to sell healthier produce in disadvantaged areas.

${ }^{\mathrm{c}}$ Kendra Wills, Extension Educator, Community Food and Environment, Michigan State University Extension, Michigan State University; 109 Logan Street SW; Grand Rapids, MI 49503 USA; willsk@msu.edu

\section{Funding Disclosure}

Funding for this study was provided by Urban Collaborators, Michigan State University Extension. 


\section{Keywords}

Food Deserts, Food Access, Alternative Grocery, Public Transit, Perception of Barriers

\section{Background and Introduction}

The U.S. Department of Agriculture (USDA) defines a food desert as an area composed of predominantly low-income neighborhoods and limited access to affordable and nutritional foods measured at a census-tract level (Liese et al., 2014; USDA Economic Research Service [USDA ERS], 2009). It further specifies metrics for defining low access in an urban region as a geographical area where $33 \%$ or more of residents are living more than one mile $(1.6 \mathrm{~km})$ from a grocery store or supermarket. It defines low income as a poverty rate of either $20 \%$ or more, or median family income falling below $80 \%$ statewide or metropolitan area family income (Ploeg et al., 2011; USDA ERS, 2009). Therefore, physical access to healthier food and affordability primarily are considered as benchmarks for identifying an area as a food desert (Liese et al., 2014; Walker et al., 2010). In 2017, the USDA reported that one in eight people in America, or $11.8 \%$ of American households, had 'low' food security, and $4.5 \%$ of households had 'very low' food security; that is, they lacked adequate financial resources and access to purchase affordable food at a grocery or supermarket (ColemanJensen et al., 2018; Hunger + Health, Feeding America, n.d.). The USDA differentiates between 'low' and 'very low' food security by considering quality, variety, or desirability of healthy foods and multiple other factors such as disrupted eating patterns and decreased food consumption (USDA ERS, 2009).

Access to foods is researched as a function of distance to grocery stores (Apparicio et al., 2007; Michimi \& Wimberly, 2010), cost, and quality of food (Wolf et al., 2005; Wetherill \& Gray, 2015). Research by Hilbert et al. (2014) included costs of both travel and products to get at the "true" expenditure on access to fresh and healthy foods. Overall, the physical distance measured is either from a census tract or block group's centroid or from the center of a supermarket or a grocery store (Jiao et al., 2012; Apparicio et al., 2007). Moreover, a straight-line (Euclidean) or street network dis- tance is used to measure distance between a selected area and a supermarket (Jiao et al., 2012; Sharkey \& Horel, 2008). Studies utilize socioeconomic characteristics such as race, income, educational attainment, and employment to assess food insecurity and access to fresh produce (Njai et al., 2017 ; Walker et al., 2010). Poorer neighborhoods have almost half the access to fruits and vegetables and nearly 30\% fewer supermarkets than higher-income neighborhoods (Wetherill \& Gray, 2015; Walker et al., 2010). Respondents with more than four years of college education are more food-secure than high-school graduates, and the least food-secure are those who do not have a high-school degree (Njai et al., 2017). White populations have perceived higher food security than other groups, including non-Hispanic whites, Blacks, and Hispanics (Block et al., 2004; Bower et al., 2013). However, Morland, Wing, and Roux (2002) found that with every unit increase in supermarkets, Blacks improved their fruit and vegetable intake by $32 \%$, and whites improved by a mere $11 \%$. Therefore, the notion of access to foods requires further investigation on the type of access and perceptions of barriers to access for a community.

Solutions to improve access to healthy foods have been linked to encouraging farmers markets, farm stands, food hubs, corner stores, and community gardens in neighborhoods in food deserts. However, some researchers have argued that the results of including alternate food retail in a neighborhood are inconsistent as it tends to depend on the context and the type of community (Alkon, 2012; Wetherill \& Gray, 2015; Njai et al., 2017). Farmers markets have a higher quality produce that offer good value for money, especially for regular patrons who are commonly females, 45 or older, affluent, with at least some college education, married, and identify as white (Alkon, 2012; Wetherill \& Gray, 2015; Wolf et al., 2005). Urban gardens are perceived as a nutrition intervention for urban residents facing barriers to achieve healthier diets by addressing limited availability to fresh produce and improving their long-term eating and consumption habits (Alaimo et al., 2008; Hoover, 2013). A farmers market in a low-income and racially segregated community is perceived to have lower acceptability 
by minorities stemming from the concept discussed by Julie Guthman (2008) as "whiteness," in addition to barriers of cost, convenience, and safety (Wetherill \& Gray, 2015). Small grocery and corner stores face poor demand to stock fresh produce at prices that are comparable to supermarkets (Pothukuchi, 2016; Raja et al., 2008). Some research has also found that studying a neighborhood food environment (within walking distance of a consumer) is insufficient to understanding the grocery shopping behavior and consumption of the low-income household's supermarket shopping pattern, as they often go outside their environment in search of 'maximizing their food dollars' (Gittelsohn et al., 2008; LeDoux \& Vojnovic, 2013). Therefore, racial segregation and cultural differences may influence the purchasing habits of people living in the same food desert area (Ver Ploeg et al., 2009).

Government programs in the U.S. such as the Supplemental Nutrition Assistance Program (SNAP) have close to 30 million people dependent on the subsidized benefits to purchase healthier nutritious food. Michigan is ranked first in the Midwest and tenth in the nation with the highest number of enrolled SNAP recipients at 615,000 (Statistical Atlas, 2018). Michigan also provides 'double-up' benefits for SNAP recipients, who can purchase fresh produce at farmers markets and other participating local food retailers to get double the amount of produce with the same amount of money (Goddeeris et al., 2017). The communityscale interventions, such as alternative payment options at local farmers markets and convenience stores, incentivize residents to purchase affordable, healthy, and nutritious foods by reducing the transportation cost and by bringing the retail source closer (Njai et al., 2017). Limited awareness about such benefits in low-income neighborhoods is a deterrent for purchasing from local farmers markets. Affordability, convenience, and safety are the other reasons recorded during focus group discussions about the benefits of these nutrition assistance programs (Wetherill \& Gray, 2015).

The aim of this study is to systematically combine multiple facets of food deserts research that have been studied by various researchers separately and get a sense of the perception of barriers to accessing fresh and healthy foods in the midwestern city of Grand Rapids, Michigan. As the secondlargest city in the state, it is ranked sixteenth in the number of SNAP enrollees and has the highest number of SNAP recipients located in southwest Michigan, with just over 20,000 married families with children (Statistical Atlas, 2018; U.S. Census Bureau, 2019). The city also introduced a free bus service called Downtown Area Shuttle (DASH) that connects key downtown nodes and runs on all days except Sunday at a frequency of 8 minutes (The Rapid, n.d.). Furthermore, the research dives into the socio-economic factors contributing to the identification of census tracts as food deserts in 2010 and 2015 and conduct interviews to determine the purchasing behavior and expenditure for families living in and around food deserts. This research also discusses policy interventions to improve the local food environment by improving access to fresh and healthy foods. Conducting this research in Grand Rapids helped explore barriers to accessing fresh and healthy foods using mixed methods and discuss opportunity to improve the perceptions of inaccessibility to parallel the efforts of community residents to improve their food environment.

\section{Materials and Methods}

\section{Data}

This project uses data from the 22 census tracts that make up the city of Grand Rapids, with 13 supermarkets with full-service grocery section and household items within the city limits. A preliminary retail price analysis was conducted on selected produce items at 11 food retail stores that were operating at the time of the study. Then, the study investigated the percentage change in socioeconomic characteristics with food desert status of the census tracts that were low income and had low access to foods. Food desert data on low income and low access census tract-level information was retrieved from the USDA Economic Research Service (ERS) online portal, Food Environment Atlas (see Figure 1) (Bao, 2017; Wadlington, 2017). The census-tract-level socioeconomic information for Grand Rapids was accessed from the U.S. Census Bureau for 2010 
Figure 1. Map of Grand Rapids, Michigan; Inset Shows Designated Food Desert Census Tracts in 2015

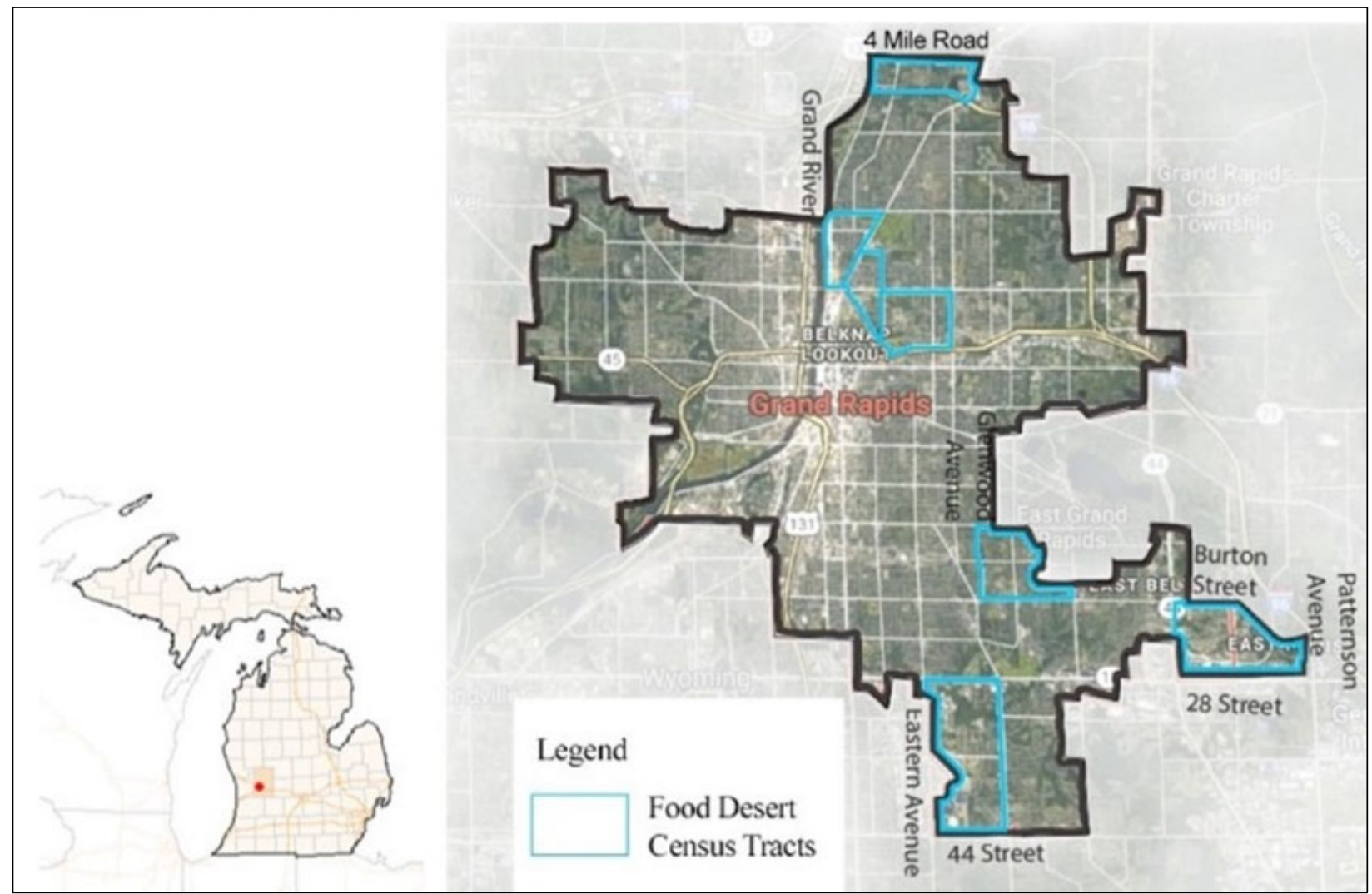

and the American Community Survey (ACS) for 2015/2016. For the spatial analyses, we obtained the transit route, bus stops, and streets layers from the Grand Rapids Open Data portal, while a complete list of mailing addresses for all residential locations in all the food desert census tracts was acquired from a private mailing list company called Melissa Data. Additionally, the information on alternate retail stores, including farmers markets, community farms, and grocery stores, was retrieved from the MSU extension office database in order to conduct the spatial analysis for the year 2015. This data for 2010 could not be verified and therefore have not been used. The study excluded convenience stores and gas stations as alternate retail stores as these have limited fresh and healthy foods

This information was imported into ArcGIS to map onto the 2010 and 2015 food deserts recorded from the Food Environment Atlas. Analyses included mapping the socio-economic characteristics by block groups in the food desert-designated cen- sus tracts for a more nuanced understanding of the residential make-up of the tracts, as well as determining whether residents were within a walking distance (quarter mile) from a bus stop to analyze their access to grocery stores, especially if they did not own a vehicle. We also mapped one mile buffers (radius) around all grocery stores (including alternate stores where fresh produce can be purchased) to see how much of the food desert census tracts were included in these buffers.

After identifying food deserts based on secondary data, the research team conducted interviews at three schools located in the food desert area using a convenience sampling method. After being granted permission from school authorities to be present on family nights and parent-teacher conference nights, the parents were interviewed on their perception of barriers to access fresh and healthy foods (Gustafsson \& Sidenvall, 2002; MacNell et al., 2017). This allowed the research team to reach families who could be living in the 
food desert-designated census tracts and get their opinions on perceived barriers to accessing healthy foods and assessing expenditure on fresh and healthy foods in stores located in food desert census tracts versus those outside (Dubowitz et al., 2015; Hendrickson et al., 2006; Walker et al., 2010). Additionally, the team canvassed some of the census tracts designated as food deserts to conduct interviews with residents. To understand the difference in the responses collected, participants who were residing in the food desert census tract were referred to as the "selected group" and the results were compared to the entire study sample, which also included residents from non-food desert designated census tracts (especially those families that lived elsewhere but whose children attend the selected schools in the food desert tracts).

The survey instrument questions such as "how often do you go grocery shopping?" "how much do you spend at the grocery store on average per trip?" and "what, in your opinion, prevents you from accessing and purchasing healthy fresh foods?" were posed after looking at similar published food access surveys (Evans et al., 2015; Mushi-Brunt et al., 2007). Respondents were also asked to list up to five stores where they regularly shopped for groceries and food products, and their address or the intersection closest to where they resided. This information was mapped in ArcGIS, and the distance traveled to access the grocery store was evaluated. This survey was also translated in Spanish and Arabic in order to engage members of ethnic minority groups who may live in the food desert-designated tracts but who did not read or understand English. The interview questionnaire was made available on Qualtrics for those who could not take part in the study at the venue. The research team also used Qualtrics to compile all the responses online. The respondents at schools received some fruit as a thank-you for participating, and interviewees reached in the food desert census tract received a US $\$ 5$ gift card to a local grocery store in the area. This study is approved and determined to be exempt by the Michigan State University Institutional Review Board, STUDY00001539.

\section{Results}

\section{Food Desert Identification}

Figure 2 is a combination of USDA-identified food deserts and author-identified grocery stores or supermarkets for 2010 and 2015. The 2010 map of Grand Rapids shows two census tracts as food deserts and 11 supermarkets or grocery stores. The 2015 map shows seven census tracts as food deserts and 13 supermarket or grocery stores. The city underwent an increase in food desert area by 2.5 times from 2010 to 2015 . Additionally, alternate retail stores were also marked on the 2015 map of

\section{Figure 2. Grand Rapids 2010 (left) and 2015 (right), USDA Defined Food Deserts with Existing Supermarkets and Alternative Food Retail Stores}

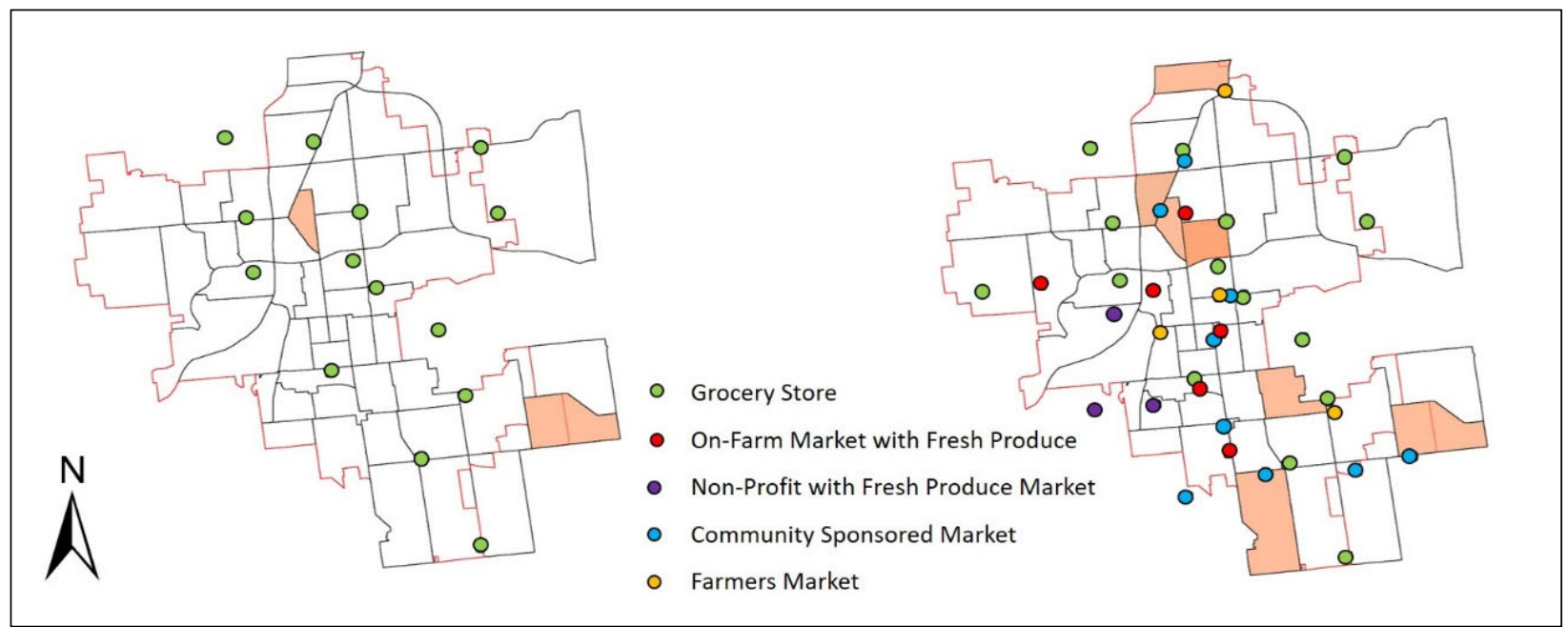


Grand Rapids. Figure 2 shows that the alternative retail stores are concentrated mainly in the middle and western edge of Grand Rapids.

\section{Role of Socio-Economic V ariables}

The data for each census tract were assessed based on percentage change for each socio-economic variable from 2010 to 2015 . The results of the socio-economic analysis are visually represented in Figure 3.

Seven census tracts were designated as food deserts in 2015 as per the USDA parameters of low income and low-access. Out of these, only two were designated as food deserts in 2010. In 2010,

Figure 3. Change in Socio-demographic Characteristics from 2010 to 2015*

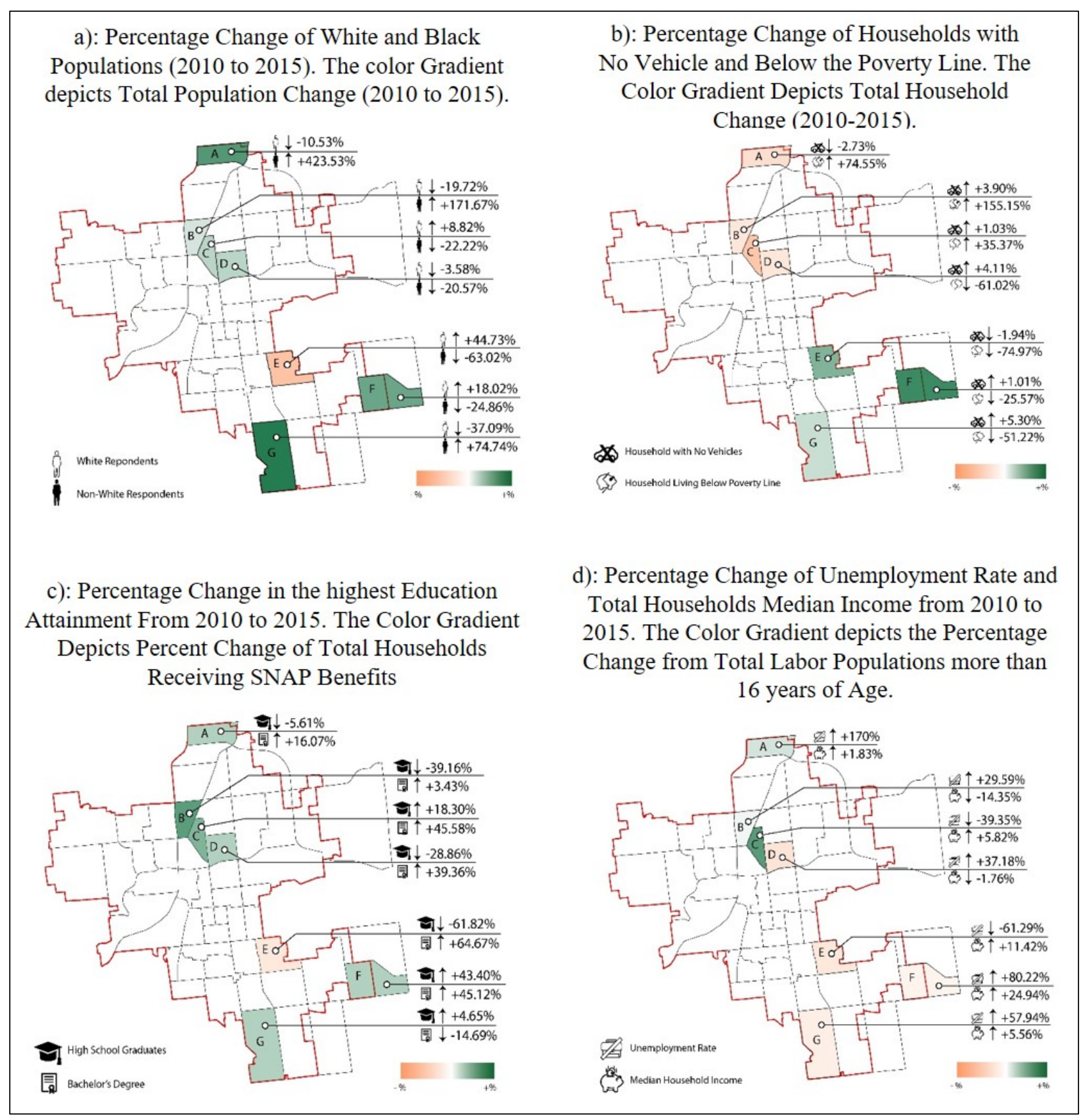

* The red outline shows the city of Grand Rapids and the black dotted lines show the census tract boundaries 
Tract $\mathrm{C}$ could have been a food desert because of the number of persons living below the poverty line $(35.37 \%)$ and households receiving SNAP benefits $(9.58 \%)$. Tract $\mathrm{F}$ also showed a higher unemployment rate compared to other census tracts and comparative median income and total labor numbers, which could have been the reason for its food desert status. However, further spatial analyses are necessitated to include alternate fresh produce stores to see if more than $33 \%$ of the population according to the parameter defined by USDA was residing more than one mile from a grocery store (USDA ERS, 2009).

The five new census tracts that became food deserts in 2015 are Tracts A, B, D, E, and G. Since unemployment rate is directly related to the median income of an area, the increase in the unemployment rate in Tract A could explain its designation as a food desert. Tracts B and D could be explained as food deserts due to their increased unemployment rates and decreased median income. In Tract $G$, an increased unemployment rate with only a marginal increase in median income could have still classified it as a food desert in 2015. Therefore, an increased unemployment rate could be a vital socio-economic indicator to underscore the emergence or existence of a food desert for future research. However, Tract E became a food desert in 2015 even with overall improving statistics. This is the only tract where the total population decreased between 2010 and 2015. Therefore, corroborating the food desert identification for this tract was similar to a myth for the researchers from socio-economic standpoint. One way to substantiate the food desert status for Tract E could be to understand market decline in the neighborhoods, possibly due to other alternate retail stores opening outside the neighborhoods, and the probability of the population living more than one mile away increasing. There is only one grocery store on the low-density southeast side. Therefore, the majority of the population could be concentrated away from the store. Hence, we conducted spatial analysis to investigate barriers to access fresh and healthy foods for this community.

\section{Spatial Analyses}

Figure 4 shows a more detailed look at race and income for the city and the food desert-designated census tracts (outlined in blue). In general, the

Figure 4. Areas within 1 Mile of a Grocery Store(Left) and 5 Minutes of a Bus Stop (Right)

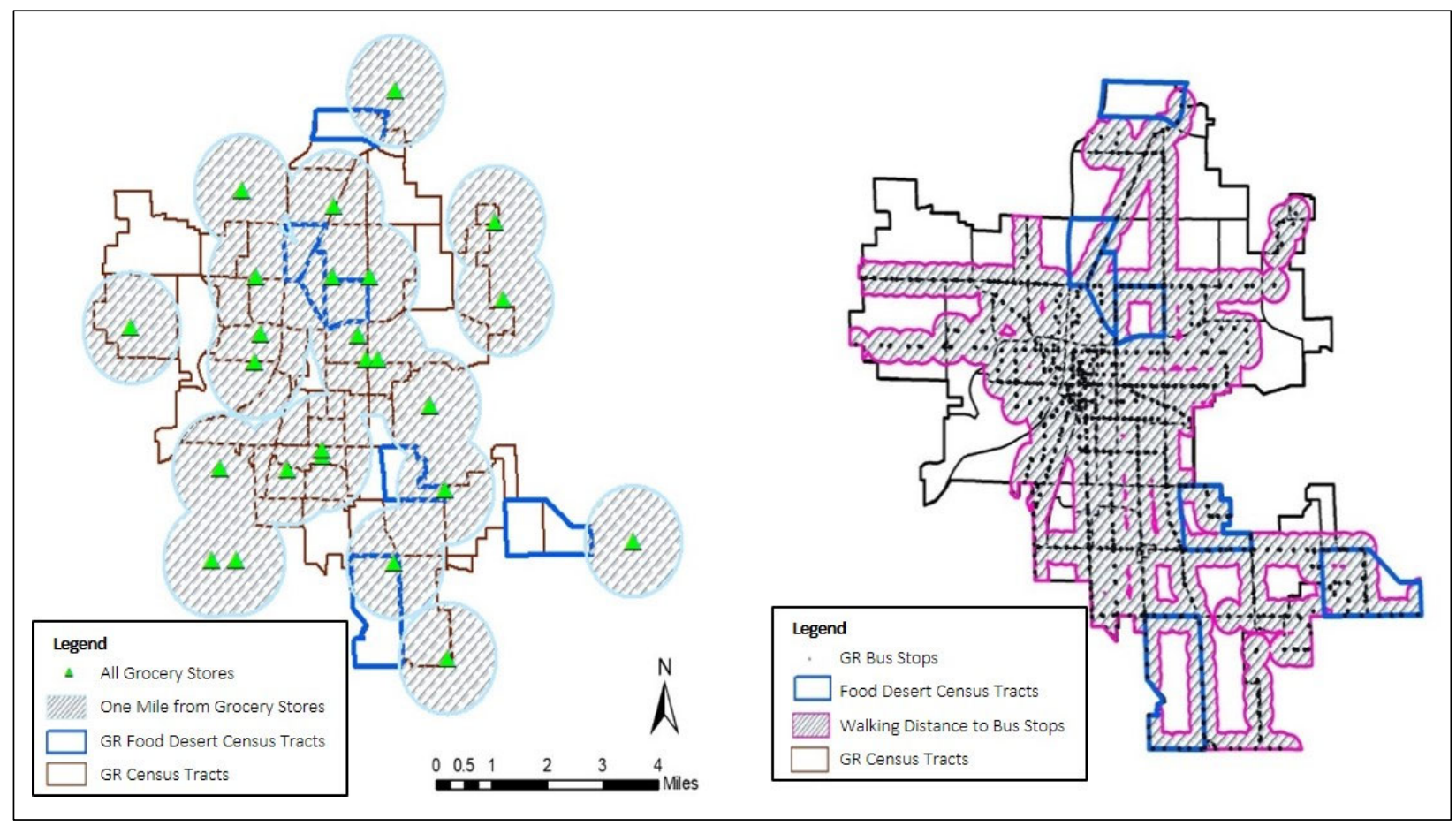


northern half of the city has a greater proportion of white and wealthier residents than the southern half of the city. The areas that have higher percentages of Black residents also have lower household incomes.

Alternative food retail stores, grocery stores, or stores that sell fresh and healthy produce were also added to our maps for spatial analyses. The addition of these show that more of the food desertdesignated census tracts are covered within a onemile radius of these stores, so including more food retail points makes sense when assessing whether people can get to fresh and healthy produce.

Accessibility to a grocery store and the designation of an area as a food desert if there is no grocery store within a one-mile radius seems less practical when residents may not have access to a vehicle and accessing a grocery store while commuting to or from work is also not feasible for them. Therefore, we assume that residents in food desert tracts who do not have access to a vehicle are critically reliant on public transit. Figure 5 shows that once other grocery stores are added to the map, many parts of food deserts get incorporated into that one-mile radius from the grocery store. This is beneficial when the residents in those food desert areas that get covered in this buffer do not have issues with access to a vehicle. A comfortable walking distance that people are willing to undertake is a quarter mile, which translates to a five-minute walk (Atash, 1994; Steuteville, 2017; Yang \& Diez-Roux, 2012). When public transit routes and bus stops are added to the map, Figure 5 shows that this fiveminute walking distance to a bus stop area includes most of the food desert tracts. We infer that someone with a lower income and no access to a vehicle would be willing to walk five minutes to get to a bus stop that would then take them to a grocery store nearby. Grand Rapids has introduced DASH, which are fare-free bus routes that connect downtown residents to multiple destinations in the center of the city, but these routes are not useful for the food desert census tracts as these are far from the city center. Therefore, the fare-free routes do not contribute to the solution of access to healthy foods for affected residents. A comparison of retail prices of randomly selected grocery items such as apples, bananas, spinach, beans, and carrots was done at all the stores in the study and we found no one store that consistently had higher or lower prices (refer to Table 1). The range of prices varied but at small rates, indicating that no one area was at

\section{Table 1. Supermarket Prices of Common Produce Items Selected}

Comparative average prices not noted if more than 3 unavailable items. Pink shading denotes highest prices, while blue shading denotes lowest prices by product.

\begin{tabular}{|c|c|c|c|c|c|c|}
\hline Supermarkets & $\begin{array}{c}\text { Apples } \\
\text { (per pound) }\end{array}$ & $\begin{array}{l}\text { Bananas } \\
\text { (per pound) }\end{array}$ & $\begin{array}{c}\text { Spinach } \\
\text { (per } 8 \text { ounces) }\end{array}$ & $\begin{array}{l}\text { Green Beans } \\
\text { (per pound) }\end{array}$ & $\begin{array}{l}\text { Raw Carrots } \\
\text { (per pound) }\end{array}$ & $\begin{array}{l}\text { Average } \\
\text { Price }\end{array}$ \\
\hline Diamond Place GFS Grocery Store & $\$ 1.89$ & $\$ 0.39$ & $\$ 3.99$ & $\$ 2.59$ & $\$ 0.89$ & $\$ 1.95$ \\
\hline Family Fare Supermarket & $\$ 1.49$ & $\$ 0.49$ & $\$ 2.75$ & $\$ 3.49$ & $\$ 0.99$ & $\$ 1.84$ \\
\hline Fresh Thyme Farmers Market & $\$ 0.99$ & $\$ 0.79$ & $\$ 2.00$ & $\$ 2.49$ & $\$ 0.89$ & $\$ 1.43$ \\
\hline Fulton Street Farmer's Market & $\$ 1.50$ & $\mathrm{~N} / \mathrm{A}$ & $\mathrm{N} / \mathrm{A}$ & $\mathrm{N} / \mathrm{A}$ & $\$ 3.00$ & $\mathrm{~N} / \mathrm{A}$ \\
\hline Great Giant & $\$ 2.99$ & $\$ 0.59$ & $\$ 2.49$ & $\$ 4.00$ & $\$ 0.96$ & $\$ 2.21$ \\
\hline Harvest Health Foods & $\$ 1.79$ & $\$ 0.49$ & $\mathrm{~N} / \mathrm{A}$ & $\$ 1.99$ & $\$ 1.99$ & $\$ 1.57$ \\
\hline Horrocks Market & $\$ 0.99$ & $\$ 0.54$ & $\$ 2.99$ & $\$ 1.99$ & $\$ 0.90$ & $\$ 1.48$ \\
\hline Ken's Fruit Market & $\$ 0.79$ & $\$ 0.39$ & $\$ 2.69$ & $\mathrm{~N} / \mathrm{A}$ & $\$ 0.79$ & $\$ 1.17$ \\
\hline Kingma's & $\$ 0.99$ & $\$ 0.59$ & $\$ 2.99$ & $\$ 2.49$ & $\$ 0.66$ & $\$ 1.54$ \\
\hline Our Family & $\$ 1.49$ & $\$ 0.54$ & $\$ 2.69$ & $\$ 2.99$ & $\$ 0.99$ & $\$ 1.74$ \\
\hline Urban Roots & $\$ 1.50$ & $\mathrm{~N} / \mathrm{A}$ & N/A & N/A & $\$ 1.50 / \$ 1.75^{*}$ & $\mathrm{~N} / \mathrm{A}$ \\
\hline
\end{tabular}

* Residents/outside. 
a greater disadvantage where access to fresh and healthy produce was concerned, when taking cost of produce into account.

Lastly, spatial proximity analyses show that while almost $59 \%(6,602)$ of the 11,173 residents who live in the seven food desert-designated census tracts fall within the one-mile buffer from the nearest grocery store, almost $75 \%(8,275)$ of these fall within a quarter mile radius of a bus stop. However, those residents living in tracts identified as having low access to a vehicle would not be able to get to the grocery store even if they lived within a mile of it. Therefore, accessibility should be understood as not only being dependent on a personal vehicle but also being afforded through public transit availability. Of the 26 routes in the Grand Rapids public transit system (The Rapids), 21 offer access to a grocery store. Thus, those residents who live in tracts designated as having low access to a vehicle need to be close to bus stops, rather than being within a mile from the grocery store. Results indicate that about $17 \%(1,900)$ of residents (out of a total of 11,173 living with food deserts) are disadvantaged, as they live in areas with low access to a vehicle and further than a fiveminute walk from the nearest bus stop (so only vehicle and transit availability is taken into consideration here). However, just under 9\% (964) of the residents living in the food desert-designated census tracts (designated by the USDA based on their low income and the fact that they live further than one mile from the nearest supermarket) live further than both metrics: one mile from a grocery store and a five-minute walk to a bus stop. Thus proximity to a grocery store and transit is taken into consideration here. These objective means of assessing access to fresh and healthy produce stress the notion that there needs to be some other inquiry into food deserts and the systemic problems with accessing fresh and healthy foods. This study took to interviews with residents as the next step in identifying perceived barriers to accessing foods.

\section{Interview Results}

From a total of 65 study participants, 13 were living in food desert census tracts (refer to Figure 2 for the location of these food desert census tracts and refer to Table 2 for some descriptive data on these participants). In all, over half (53\%) of study participants living in the food desert-designated census tracts said they did not face any barriers to accessing fresh and healthy produce, compared to $62 \%$ of all those interviewed. Twenty-five percent of the participants reported having an annual household income less than US $\$ 25,000$, whereas less than $8 \%$ reported having the same income range in the food desert tracts. More than $95 \%$ of the study participants had access to a car. Thirty-six percent of respondents who travel by car for their grocery shopping $(n=61)$ said they faced barriers to accessing fresh and healthy foods, and $75 \%$ of respondents who use other modes of travel $(n=4)$ reported facing barriers to access fresh and healthy foods. With the city of Grand Rapids' efforts in improving accessibility for all, this city has been able to address the transportation barrier for some members of minority populations; however, this remains to be further studied to analyze its use and efficacy.

Respondents from the group of participants who lived within the food deserts spent more on average per week for groceries, prepared meals, and eating out compared to all respondents, although this difference was not statistically significant. Fifty percent of white respondents who perceived barriers $(n=8)$ spent more than US $\$ 100$ on average per week on groceries while only $17 \%$ of Black respondents who faced barriers $(n=12)$ spent greater than US $\$ 100$ on average per week on groceries. Even with nutrition assistance, people living in food deserts tend to spend more on groceries than those who are not living in food deserts.

Overall, of those who reported facing barriers to accessing fresh and healthy foods $(n=25)$, twothirds were non-white respondents and one-third were white respondents. Affordability was the main perceived barrier for the majority of the households on SNAP or some food and nutrition assistance and by non-white respondents. Additionally, access to seasonal produce and awareness about local food retail entities were also identified as barriers to consuming fresh and healthy produce. The average travel distance for the overall group was 3.9 miles $(6.3 \mathrm{~km})$, whereas for the group living in the food deserts, it was 4.1 miles $(6.6 \mathrm{~km})$. The distance was marginally longer $(0.2$ miles or $0.3 \mathrm{~km})$; 
however, this difference is not statistically significant. This part of the study indicates that even with access to fresh and healthy produce being identified through the spatial analyses, some residents still perceive that there are barriers that prevent them from acquiring produce, and costs and lack

Table 1. Interviewees' Socio-demographic Data and Expenditures on Groceries, Prepared Meals, and Eating Out

Some figures have been rounded

\begin{tabular}{|c|c|c|}
\hline Socio-Demographic Variable & $\begin{array}{c}\text { Survey } \\
\text { Participants }\end{array}$ & $\begin{array}{l}\text { Selected } \\
\text { Group }\end{array}$ \\
\hline Population $(n)$ & 65 & 13 \\
\hline \multicolumn{3}{|l|}{ Gender } \\
\hline Male & $18 \%$ & $23 \%$ \\
\hline Female & $82 \%$ & $77 \%$ \\
\hline \multicolumn{3}{|l|}{ Race } \\
\hline White & $45 \%$ & $70 \%$ \\
\hline Black & $43 \%$ & $23 \%$ \\
\hline Others & $12 \%$ & $7 \%$ \\
\hline \multicolumn{3}{|l|}{ Number of Household Members } \\
\hline 0 to 2 & $23.5 \%$ & $31 \%$ \\
\hline 3 to 5 & $62.5 \%$ & $46 \%$ \\
\hline More than 6 & $14 \%$ & $23 \%$ \\
\hline \multicolumn{3}{|l|}{ Children at home } \\
\hline 0 & $19 \%$ & $31 \%$ \\
\hline 1 & $28.5 \%$ & $23 \%$ \\
\hline 2 & $28.5 \%$ & $23 \%$ \\
\hline 3 & $13 \%$ & $8 \%$ \\
\hline 4 or more & $11 \%$ & $15 \%$ \\
\hline SNAP-EBT Users & $16 \%$ & $8 \%$ \\
\hline Perceive Barriers to Access Fresh and Healthy Foods & $39 \%$ & $46 \%$ \\
\hline \multicolumn{3}{|l|}{ Vehicles at home } \\
\hline 0 & $3 \%$ & $0 \%$ \\
\hline 1 or more & $97 \%$ & $100 \%$ \\
\hline \multicolumn{3}{|l|}{ Education } \\
\hline High school graduate or less & $30 \%$ & $31 \%$ \\
\hline Some college credit/no degree & $34.5 \%$ & $54 \%$ \\
\hline Bachelors & $17 \%$ & $8 \%$ \\
\hline Graduate degree & $18.5 \%$ & $8 \%$ \\
\hline \multicolumn{3}{|l|}{ Employment } \\
\hline Employed for wages & $66 \%$ & $61.5 \%$ \\
\hline Self-employed & $14 \%$ & $15.5 \%$ \\
\hline Others & $20 \%$ & $23 \%$ \\
\hline \multicolumn{3}{|l|}{ Number of Grocery Trips per week } \\
\hline Less than twice & $79 \%$ & $85 \%$ \\
\hline Three to five times & $18 \%$ & $15 \%$ \\
\hline Six or more times & $3 \%$ & $0 \%$ \\
\hline Average Expenditure on Groceries per trip & $\$ 106$ & $\$ 112$ \\
\hline Expenditure on Prepared Meals per week & $\$ 29$ & $\$ 33$ \\
\hline Expenditure on Eating Out per week & $\$ 35$ & $\$ 42$ \\
\hline
\end{tabular}

of awareness of produce availability were the main barriers identified.

\section{Discussion}

This study brings out a few things. First, the objective measures used to designate food deserts need to be revisited. The designation comes from a federal agencythe USDA — and so their designation is an important first step in many research endeavors related to food access. If this first step is revised or improved, research starts off on a better note and we get to the underlying structural issues directly. Access to supermarkets is a good starting point for fresh and healthy produce; however, residents usually frequent stores based on many other factors as well (Bailey, 2010; Caspi, Sorensen, et al., 2012; Gittelsohn et al., 2008; Ledoux \& Vojnovic, 2013; National Research Council, 2009). Access to alternate food retail markets, including farmers markets, should be considered apart from supermarkets when designating census tracts as food deserts (Evans et al., 2012; Kwate, 2008). Our results show that with the addition of alternate food retail stores, about $59 \%$ of residents fall within the one-mile radius of grocery stores. That still leaves about $40 \%$ of residents as being disadvantaged. In this study, some of the new alternate retail stores were found to be on the geographical edges of the food desert census tracts and not located in the food desert area except in a limited number of cases. Presently, there is a greater percentage of alternate food retail stores in comparatively 
more affluent neighborhoods than the ones which were identified as food desert in 2015, which is consistent with the food market tendency of setting up in economically stronger neighborhoods (Zenk et al., 2006). This strategic location for the alternate food retailers suggests that the efforts to bring these food retailers in close proximity to areas of low income and low access to healthy foods still fail to capture the entire census tract where their need is most vital (Kwate, 2008).

Apart from including alternate food retail stores, we must also consider travel modes other than the personal vehicle. Those with no access to a vehicle inherently will be reliant on public transportation. Results of this study showed that once we included the transit routes and bus stops into the spatial analyses, $75 \%$ percent of the residents in the food desert-designated census tracts had access to a grocery store. Combining the alternate stores and public transit, $91 \%$ of residents in food desert census tracts had access to a grocery store with fresh and healthy produce.

Second, this research brings forward the structural imbalances in resident classes and racial groups, since minority groups reported a greater barrier to accessing fresh and healthy foods than white residents living in the same food desertdesignated census tracts, echoing research findings from Kwate (2008). Interviewees living in the food deserts areas reported fewer trips to the grocery store per week and higher expenses per trip compared to interviewees living outside the food desert tracts. These interviewees also reported higher expenditures on prepared meals and eating out, supporting findings by other researchers on the topic (Alwitt \& Donley, 1997; Chung \& Myers, 1999). Affordability and awareness of alternative venues for accessing fresh and healthy foods were the greatest barriers reported. Since most respondents reported having access to a private vehicle and being five minutes from public transit, the objective measures of access do not seem to be the issue as much as the subjective measures of access, more specifically cost and awareness of availability and acceptance of SNAP benefits, echoing the findings by Caspi, Kawachi, et al. (2012). Research often proposes objective measures of access, such as distance to stores, time spent in travel to stores, costs associated with travel to stores (whether they be personal costs for using a car or costs associated with public transit), and costs associated with buying a set of products from stores (Hendrickson et al., 2006; Walker et al., 2010). As reflected by Ver Ploeg et al. (2009) as to the importance of race and cultural differences in food purchasing habits of residents, this research adds knowledge on the topic by asking residents about their perception, as urged by Usher (2015), of barriers to accessing fresh and healthy produce after analyzing the objective measures of access.

This study has a few limitations. First, the study could not access data on supermarkets and grocery stores that closed or opened between 2010 and 2015 to analyze whether that played a role in the change of food desert designation. Second, the sample size for interviews in this study is comparatively small, and therefore cannot be generalized for the entire city. Third, ethnic minorities may have not been fully represented in the selected group due to language limitations and respondents with children may have been overrepresented during the interviews that were conducted in primary schools. Lastly, the distances used in the spatial analyses were radii from the point of interest (grocery store or bus stop) rather than network-based travel distances. However, similar patterns of food desert characteristics such as income, employment, education, and race are visible in its urban fabric.

\section{Conclusions}

This research delves into the nuances involved when assessing access to fresh and healthy foods. Grand Rapids, Michigan, with its geographic divide created by the Grand River and industrial complexes, has long-standing racial and ethnic segregation. The results of the qualitative analyses in this study show that minority groups perceived a greater barrier to accessing fresh and healthy food than whites, even when living in the same census tracts. This research also showed that that access to food involves more than just supermarkets and driving distances to such supermarkets. It involves, perhaps more importantly, inclusion of alternative grocery stores that offer fresh and healthy produce at affordable prices, and the presence of a public transportation system that can grant access to such 
destinations for those lower-income residents who do not have access to a private vehicle. This study thus proposes that the inclusion of alternate retail stores with fresh and healthy produce be encouraged and in-place corner stores be incentivized to carry and sell healthier produce items. Another take-away from this study is that location within a mile of a grocery store is misleading if the residents do not have a car to get there. However, being able to access another mode of public transit to get to a grocery store is also an important and practical aspect to consider when mitigating barriers to access fresh and healthy foods. Home delivery of grocery items that is developing rapidly from local food retail stores could contribute to the last-mile connectivity to healthy foods for those who do not own a vehicle. Current conditions due to the COVID-19 pandemic have fueled the practice of groceries being delivered to the consumers. This form of access to fresh produce addresses the physical distance and mode of travel to obtain fresh produce. However, this does not address the equity issue with access, as being able to get groceries delivered home involves a subscription to a delivery service or payment of a delivery charge, perpetuating the disadvantage and burden that food-insecure families face.

One of the important findings of this research is that even with a presence of alternate grocery stores and the availability of transit which, in general, would lift a vast majority of the residents in food desert areas out of the "inaccessible to grocery stores" category, the residents still perceive barriers to accessing fresh and healthy foods. Cost was reported as the main perceived barrier to accessing healthy foods by the residents in the food desert census tracts. Awareness of alternative retail stores that accept federal program dollars was a close second and therefore an increase in the awareness would enable access for residents on income support and food assistance programs to a large extent. Similarly, retail stores frequented by consumers living in food deserts should be incentivized to include fresh and healthy foods to promote a healthier environment for residents, as people tend to patronize sellers with a selling history or similar cultural backgrounds in their neighborhood. With more digital interventions, targeted and subsidized delivery for EBT beneficiaries may be explored to promote convenience of purchasing fresh and healthy foods.

Knowing the divide in perceived barriers by race and class of residents in the same built environment, the questions that need further research are: what are the residents trying to purchase, what is "affordable" as far as costs go? Further research is recommended to include information on customer purchasing patterns and market trends including delivery schemes offered for grocery retail when there are increasing numbers of food deserts in Grand Rapids and in similar cities.

Regarding racial diversity, the food assistance programs should be assessed with respect to the race and ethnicity of the minority populations so that it is easier for the communities to adapt and achieve a better quality of life with access to a healthier diet for themselves and their families. Maybe it is time to move away from the "food desert" designation to something that is more representative of a phenomenon that is in no way "natural" like a desert, but the result of longstanding and persistent economic and structural actions that have led to poor access to fresh and healthy produce for many underrepresented residents.

\section{References}

Alaimo, K., Packnett, E., Miles, R. A., \& Kruger, D. J. (2008). Fruit and vegetable intake among urban community gardeners. Journal of Nutrition, Education and Behavior, 40, 94-101. https://doi.org/10.1016/j.jneb.2006.12.003

Alwitt, L. F., \& Donley, T. D. (1997). Retail stores in poor urban neighborhoods. Journal of Consumer Affairs, 311, 139-164. https://doi.org/10.1111/j.1745-6606.1997.tb00830.x

Alkon, A. (2012). Black, white, and green: Farmers markets, race, and the green economy. University of Georgia Press.

Apparicio, P., Cloutier, M.-S., \& Shearmur, R. (2007). The case of Montréal's missing food deserts: Evaluation of accessibility to food supermarkets. International Journal of Health Geographics, 6(4).

https://doi.org/10.1186/1476-072X-6-4 
Atash, F. (1994). Redesigning suburbia for walking and transit: Emerging concepts. Journal of Urban Planning and Development, 120(1), 48-57. https://doi.org/10.1061/(ASCE)0733-9488(1994)120:1(48)

Bailey, A. R. (2010). Consumer behaviour and the life course: Shopper reactions to self-service grocery shops and supermarkets in England. Environment and Planning A: Economy and Space, 42(6), 1496-1512. https://doi.org/10.1068/a42247

Bao, Y. (2017). The geography of urban food access: Exploring the spatial and socioeconomic dimensions (Publication No. 10275767) [Doctoral dissertation, University of Arizona]. ProQuest Dissertations Publishing.

Block, J., Scribner, R., \& DeSalvo , K. (2004). Fast food, race/ethnicity, and income: A geographic analysis. American Journal of Preventive Medicine, 27(3), 211-217. https://doi.org/10.1016/j.amepre.2004.06.007

Bower, K. M., Thorpe, R. J., Rohde, C., \& Gaskin, D. J. (2013). The intersection of neighborhood racial segregation, poverty, and urbanicity and its impact on food store availability in the United States. Preventive Medicine, 58, 33-39. https://doi.org/10.1016/j.ypmed.2013.10.010

Caspi, C. E., Kawachi, I., Subramanian, S. V., Adamkiewicz, G., \& Sorensen, G. (2012). The relationship between diet and perceived and objective access to supermarkets among low-income housing residents. Social Science \& Medicine, 75(7), 1254-1262. https://doi.org/10.1016/i.socscimed.2012.05.014

Caspi, C. E., Sorensen, G., Subramanian, S. V., \& Kawachi , I. (2012). The local food environment and diet: A systematic review. Health \& Place, 18(5), 1172-1187. https://doi.org/10.1016/j.healthplace.2012.05.006

Chung, C., \& Myers Jr, S. L. (1999). Do the poor pay more for food? An analysis of grocery store availability and food price disparities. Journal of Consumer Affairs, 33(2), 276-296. https://doi.org/10.1111/j.1745-6606.1999.tb00071.x

Coleman-Jensen, A., Rabbitt, M. P., Gregory, C. A., \& Singh, A. (2018). Household food security in the United States in 2017 (Economic Research Report No. 256). USDA Economic Research Service. https://www.ers.usda.gov/webdocs/publications/90023/err-256.pdf

Dubowitz, T., Zenk, S. N., Ghosh-Dastidar, B., Cohen, D. A., Beckman, R., Hunter, G., Steiner, E. D., \& Collins, R. L. (2015). Healthy food access for urban food desert residents: examination of the food environment, food purchasing practices, diet and BMI. Public Health Nutrition, 18(12), 2220-2230. https://doi.org/10.1017/S1368980014002742

Evans, A., Banks, K., Jennings, R., Nehme, E., Nemec, C., Sharma, S., Hussaini, A., \& Yaroch, A. (2015). Increasing access to healthful foods: A qualitative study with residents of low-income communities. International Journal of Behavioral Nutrition, 12(Suppl. 1), S5. https://doi.org/10.1186/1479-5868-12-S1-S5

Evans, A. E., Jennings, R., Smiley, A. W., Medina, J. L., Sharma, S. V., Rutledge, R., Stigler, M. H., \& Hoelscher, D. M. (2012). Introduction of farm stands in low-income communities increases fruits and vegetable among community residents. Health \& Place, 18(5),1137-1143. https://doi.org/10.1016/i.healthplace.2012.04.007

Gittelsohn, J., Franceschini, M. C., Rasooly, I. R., Ries, A. V., Ho, L. S., Pavlovich , W., Santos, V. T., Jennings, S. M., \& Frick, K. D. (2008). Understanding the food environment in a low-income urban setting: Implications for food store interventions. Journal of Hunger \& Environmental Nutrition, 2(2-3), 33-50.

https://doi.org/10.1080/19320240801891438

Goddeeris, L., Mann, J., O’Hara, J., Miller, S., Trumbull, E., \& Pirog, R. (2017). Analysis of healthy food incentive programs' impact on farmers market vendors in Michigan. Michigan State University Center for Regional Food Systems. https://www.canr.msu.edu/resources/analysis-of-healthy-food-incentive-programs-impact-on-farmers-marketvendors-in-michigan

Gustafsson, K., \& Sidenvall, B. (2002). Food-related health perceptions and food habits among older women. Journal of Advanced Nursing, 39(2), 164-173. https://doi.org/10.1046/j.1365-2648.2002.02256.x

Guthman, J. (2008). "If they only knew": Color blindness and universalism in California alternative food institutions. The Professional Geographer, 60(3), 387-397. https://doi.org/10.1080/00330120802013679

Hendrickson, D., Smith, C., \& Eikenberry, N. (2006). Fruit and vegetable access in four low-income food deserts communities in Minnesota. Agriculture and Human Values, 23, 371-383. https://doi.org/10.1007/s10460-006-9002-8

Hilbert, N., Evans-Cowley, J., Reece, J., Rogers, C., Ake, W., \& Hoy, C. (2014). Mapping the cost of a balanced diet, as a function of travel time and food price. Journal of Agriculture, Food Systems, and Community Development, 5(1), $105-127$. https://doi.org/10.5304/jafscd.2014.051.010 
Hoover, B. (2013). White spaces in black and Latino places: Urban agriculture and food sovereignty. Journal of Agriculture, Food Systems, and Community Development, 3(4), 109-115. https://doi.org/10.5304/jafscd.2013.034.014

Hunger + Health, Feeding America. (n.d.). Understanding food insecurity. Retrieved December 2, 2018, from https://hungerandhealth.feedingamerica.org/understand-food-insecurity/

Jiao, J., Moudon, A. V., Ulmer, J., Hurvitz, P. M., \& Drewnowski, A. (2012). How to identify food deserts: Measuring physical and economic access to supermarkets in King County, Washington. American Journal of Public Health, 102(10), e32-e39. https://doi.org/10.2105/AJPH.2012.300675

Kwate, N. O. A. (2008). Fried chicken and fresh apples: Racial segregation as a fundamental cause of fast food density in Black neighborhoods. Health \& Place, 14(1), 32-44. https://doi.org/10.1016/i.healthplace.2007.04.001

LeDoux, T. F., \& Vojnovic, I. (2013). Going outside the neighborhoods: The shopping patterns and adaptations of disadvantaged consumers living in the lower eastside neighborhoods of Detroit, Michigan. Health \& Place, 19, 1-14. https://doi.org/10.1016/i.healthplace.2012.09.010

Liese, A. D., Hibbert, J. D., Ma, X., Bell, B. A., \& Battersby, S. E. (2014). Where are the food deserts? An evaluation of policy-relevant measures of community food access in South Carolina. Journal of Hunger \& Environmental Nutrition, 9(1), 16-32. https://doi.org/10.1080/19320248.2013.873009

MacNell, L., Elliott, S., Hardison-Moody, A., \& Bowen, S. (2017). Black and Latino urban food desert residents' perceptions of their food environment and factors that influence food shopping decisions. Journal of Hunger \& Environmental Nutrition, 12(3), 375-393. https://doi.org/10.1080/19320248.2017.1284025

Michimi, A., \& Wimberly, M. C. (2010). Associations of supermarket accessibility with obesity and fruit and vegetable consumption in the conterminous United States. International Journal of Health Geographics, 9, Article 49. https://doi.org/10.1186/1476-072X-9-49

Morland, K., Wing, S., \& Roux, A. D. (2002). The contextual effect of the local food environment on residents' diets: The atherosclerosis risk in communities study. American Journal of Public Health, 92, 1761-1768. https://doi.org/10.2105/aiph.92.11.1761

Mushi-Brunt, C., Haire-Joshu, D., \& Elliott, M. (2007). Food spending behaviors and perceptions are associated with fruit and vegetable intake among parents and their preadolescent children. Journal of Nutrition Education and Behavior, 39(1), 26-30. https://doi.org/10.1016/j.jneb.2006.06.004

National Research Council. (2009). The public health effects of food deserts. National Academies Press. https://www.ncbi.nlm.nih.gov/books/NBK208011/

Njai, R., Siegel, P., Yin, S., \& Liao, Y. (2017). Prevalence of perceived food. Morbidity and Mortality Weekly Report, 66(1), 12-15. https://doi.org/10.15585/mmwr.mm6601a2

Ploeg, M. V., Nulph, D., \& Williams, R. (2011). Mapping food deserts in the United States. U.S. Department of Agriculture, Economic Research Service. https:/ / www.ers.usda.gov/amber-waves/2011/december/data-feature-mapping-food-deserts-in-the-us/

Pothukuchi, K. (2016). Bringing fresh produce to corner stores in declining neighborhoods: Reflections from Detroit FRESH. Journal of Agriculture, Food Systems, and Community Development, 7(1), 113-134. https://doi.org/10.5304/jafscd.2016.071.013

Raja, S., Ma, C., \& Yadav, P. (2008). Beyond food deserts: Measuring and mapping racial disparities in neighborhood food environments. Journal of Planning Education and Research, 27(4), 469-482. https://doi.org/10.1177/0739456X08317461

Sharkey, J. R., \& Horel, S. (2008). Neighborhood socioeconomic deprivation and minority composition are associated with better potential spatial access to the ground-truthed food environment in a large rural area. The Journal of Nutrition, 138(3), 620-627. https://doi.org/10.1093/in/138.3.620

Statistical Atlas. (2018). Food stamps in Michigan (State). Retrieved Sept. 4, 2018, from https://statisticalatlas.com/state/Michigan/Food-Stamps

Steuteville, R. (2017). Great idea: Pedestrian shed and the 5-minute walk. Public Square. https://www.cnu.org/publicsquare/2017/02/07/great-idea-pedestrian-shed-and-5-minute-walk 
The Rapid. (n.d.). DASH the Downtown Area Shuttle. Retrieved Sept. 4, 2018, from https://www.ridetherapid.org/additionalservices/DASH\#: :text=The $\% 20$ Downtown $\% 20$ Area $\% 20$ Shuttle $\% 2 C \% 20$ or, core $\% 20$ of $\% 20$ downtown $\% 20$ Gran $\underline{\mathrm{d} \% 20 \text { Rapids }}$

U.S. Census Bureau. (2019). Food Stamps/Supplemental Nutrition Assistance Program (SNAP). https://data.census.gov/cedsci/table? $\mathrm{q}=$ grand $\% 20 \mathrm{rapids}, \% 20 \mathrm{michigan} \& \mathrm{t}=\mathrm{SNAP} \% 2 \mathrm{FFood} \% 20 \mathrm{Stamps} \& \mathrm{tid}=\mathrm{ACS}$ $\underline{\text { ST1Y2019.S2201\&hidePreview }=\text { false }}$

U.S. Department of Agriculture Economic Research Service [USDA ERS]. (2009). Access to affordable and nutritious food: Measuring and understanding food deserts and their consequences. https://www.ers.usda.gov/webdocs/publications/42711/12700 ap036a 1 .pdf?v $=0$

Usher, K. (2015). Valuing all knowledges through an expanded definition of access. Journal of Agriculture, Food Systems, and Community Development, 5(4), 109-114. https://doi.org/10.5304/jafscd.2015.054.018

Ver Ploeg, M., Breneman, V., Dutko, P., Williams, R., Snyder, S., Dicken, C., \& Kaufman, P. (2012). Access to affordable and nutritious food: Updated estimates of distance to supermarkets using 2010 data. USDA Economic Research Service. https://doi.org/10.22004/ag.econ.262227

Ver Ploeg, M., Breneman, V., Farrigan, T., Hamrick, K., Hopkins, D., Kaufman, P., Lin, B.-H., Nord, M., Smith, T., Williams, R., Kinnison, K., Olander, C., Singh, A., \& Tuckermanty, E. (2009). Access to affordable and nutritious food: measuring and understanding food deserts and their consequences: Report to congress (Report No. AP-036). USDA Economic Research Service. https://www.ers.usda.gov/publications/pub-details/?pubid=42729

Wadlington, T. D. (2017). Access to healthy foods: A descriptive analysis of farmers' markets, food deserts \& USD A food assistance programs in Tennessee census tracts [Doctoral dissertation, East Tennessee State University]. Digital Commons @ East Tennessee State University. https://dc.etsu.edu/etd/3326/

Walker, R. E., Keane, C. R., \& Burke, G. J. (2010). Disparities and access to healthy food in the United States: A review of food deserts literature. Health \& Place, 16(5), 876-884. https://doi.org/10.1016/j.healthplace.2010.04.013

Wetherill, M. S., \& Gray, K. A. (2015). Farmers' markets and the local food environment: identifying perceived accessibility barriers for SNAP consumers receiving temporary assistance for needy families (TANF) in an urban Oklahoma community. Journal of Nutrition Education and Behavior, 47(2), 127-133. https://doi.org/10.1016/j.jneb.2014.12.008

Wolf, M. M., Spittler, A., \& Ahern, J. (2005). A profile of farmers' market consumers and perceived advantages of produce sold at farmers' markets. Journal of Food Distribution Research, 36, 192-201. https://doi.org/10.22004/ag.econ.26768

Yang, Y., \& Diez-Roux, A. V. (2012). Walking distance by trip purpose and population subgroups. American Journal of Preventive Medicine, 43(1), 11-19. https://doi.org/10.1016/j.amepre.2012.03.015

Zenk, S. N., Schulz, A. J., Israel, B. A., James, S. A., Bao, S., \& Wilson, M. L. (2006). Fruit and vegetable access differs by community racial composition and socioeconomic position in Detroit, Michigan. Ethnicity and Disease, 16(1), 275-280. https://www.ncbi.nlm.nih.gov/pubmed/16599383 